\title{
Prestasi Belajar Akuntansi Melalui Model Pembelajaran Problem Based Learning Pada Siswa Kelas XI MA Al Hidayah Muara Telang Kabupaten Banyuasin
}

\author{
Ratna Dewi AR*, Musa Thahir** \\ * Guru MA Al Hidayah Muara Telang, Provinsi Sumatera Selatan \\ ** Pendidikan Matematika, Universitas Islam Negeri Sultan Syarif Kasim Riau
}

\begin{tabular}{|c|c|}
\hline INFO ARTIKEL & ABSTRAK \\
\hline Riwayat Artikel: & Abstract: This research is motivated by the interest and motivation of students to study accounting \\
\hline $\begin{array}{l}\text { Diterima: } 6 \text { Maret } 2018 \\
\text { Disetujui: } 10 \text { Juni } 2018\end{array}$ & $\begin{array}{l}\text { is still low, both internal motivation and external motivation. Based on existing problems, this study } \\
\text { aims to describe the implementation of Problem Based Learning model of learning in improving the } \\
\text { achievement of accounting learning in grade XI students MA Al Hidayah Muara Telang Banyu Asin } \\
\text { District. This research method using Classroom Action Research approach (PTK). In Classroom }\end{array}$ \\
\hline Kata kunci: & $\begin{array}{l}\text { Action Research (PTK) is the subject of research is the student class XI IPS consisting of } 37 \text { students. } \\
\text { The techniques used in this study are observation, documentation, and tests. While the data analysis }\end{array}$ \\
\hline $\begin{array}{l}\text { Problem Based Learning } \\
\text { Prestasi Belajar } \\
\text { Akuntansi }\end{array}$ & $\begin{array}{l}\text { used is comparative descriptive data analysis, and qualitative analysis. The results showed that the } \\
\text { overall application of Problem Based Learning model has been able to improve student achievement. } \\
\text { This is evident from the achievement of the average value of students and the number of students who } \\
\text { reach the limit of mastery. }\end{array}$ \\
\hline
\end{tabular}

\begin{abstract}
Abstrak: Artikel ini dilatarbelakangi oleh minat dan motivasi siswa untuk belajar akuntansi masih rendah, baik motivasi internal maupun motivasi eksternal. Berdasarkan masalah yang ada, penelitian ini bertujuan untuk mendeskripsikan penerapan model pembelajaran Problem Based Learning dalam meningkatkan prestasi belajar akuntansi pada siswa kelas XI MA Al Hidayah Muara Telang Kabupaten Banyu Asin. Metode penelitian ini menggunakan pendekatan Penelitian Tindakan Kelas (PTK). Dalam Penelitian Tindakan Kelas (PTK) ini yang menjadi subjek penelitian adalah siswa kelas XI IPS yang terdiri dari 37 siswa. Teknik yang digunakan dalam penelitian ini adalah observasi, dokumentasi, dan tes. Sedangkan analisis data yang digunakan adalah analsis data deskriptif komparatif, dan analsis kualitatif. Hasil penelitian menunjukkan bahwa secara keseluruhan penerapan model Problem Based Learning telah dapat meningkatkan prestasi belajar siswa. Hal ini terbukti dari pencapaian nilai rata-rata siswa dan jumlah siswa yang mencapai batas ketuntasan.
\end{abstract}

\section{Alamat Korespondensi:}

Ratna Dewi AR,

Guru MA Al Hidayah Muara Telang, Provinsi Sumatera Selatan

Muara Telang, Sumber Marga Telang, Kabupaten Banyu Asin, Sumatra Selatan 30974

E-mail: ratna.dewrar@gmail.com 


\section{LATAR BELAKANG}

Pembelajaran merupakan suatu proses interaksi (hubungan timbal balik) antara guru dan siswa atau pembelajar beserta unsur-unsur yang ada di dalamnya. Pembelajaran merupakan bagian dari Pendidikan, yang di dalamnya ditunjang oleh berbagai unsur-unsur pembelajaran antara lain tujuan, materi pelajaran, sarana prasarana, situasi atau kondisi belajar, media pembelajaran, lingkungan belajar, metode pembelajaran, serta evaluasi. Kesemua unsur-unsur pembelajaran tersebut sangat mempengaruhi keberhasilan proses pembelajaran untuk meningkatkan prestasi belajar siswa. Proses pembelajaran dipengaruhi oleh dua faktor (Yona, 2011). Faktor pertama adalah faktor yang berasal dari dalam dan faktor yang kedua adalah faktor yang berasal dari luar siswa, sedangkan faktor yang berasal dari luar diri siswa salah satunya adalah metode pembelajaran. Penggunaan metode yang tepat sangat mempengaruhi keberhasilan proses pembelajaran. Akan tetapi, kenyataan yang ada saat ini bahwa masih banyak guru yang menggunakan metode tidak melibatkan siswa secara aktif dalam proses pembelajaran sehingga tidak sesuai dengan harapan setiap guru di sekolah.

Permasalahan yang timbul adalah pendidikan kita masih didominasi oleh pandangan bahwa pengetahuan sebagai perangkat fakta-fakta yang harus dihafal, termasuk mata pelajaran akuntansi. Di sisi lain adanya banyak fakta bahwa guru menguasai materi suatu subjek dengan baik tetapi tidak dapat melaksanakan kegiatan pembelajaran dengan baik. Hal itu terjadi karena kegiatan tersebut tidak didasarkan pada model pembelajaran tertentu sehingga prestasi belajar yang diperoleh siswa rendah. Proses pembelajaran di dalam kelas masih berfokus pada guru sebagai sumber utama pengetahuan, dimana ceramah menjadi pilihan utama proses pembelajaran. Seperti halnya pada siswa kelas XI IPS MA Alhidayah Muara Telang menghadapi permasalahan tersebut. Hal ini dilihat berdasarkan observasi awal yang dilakukan oleh peneliti menunjukkan bahwa minat dan motivasi siswa untuk belajar akuntansi masih rendah, baik motivasi internal maupun motivasi eksternal. Agar upaya tersebut berhasil maka harus dipilih model pembelajaran yang sesuai dengan situasi dan kondisi siswa serta lingkungan belajar, siswa dapat aktif, interaktif dan kreatif dalam proses pembelajaran. Pemilihan model pembelajaran yang tepat merupakan manifestasi dari kreatifitas seorang guru agar siswa tidak jenuh atau bosan dalam menerima pelajaran. Pemilihan model pembelajaran yang tepat juga akan memperjelas konsep-konsep yang diberikan kepada siswa senantiasa antusias berfikir dan berperan aktif.

Model pembelajaran yang efektif dapat digunakan guru untuk mentransfer ilmu dengan baik dan benar, baik secara langsung maupun tidak langsung. Model pembelajaran akan efisien jika menghasilkan kemampuan siswa seperti yang diharapkan dalam tujuan dan sesuai dengan target perhitungan dalam segi materi dan waktu. Seorang guru sebaiknya mampu memilih model yang tepat bagi siswa didiknya. Pemilihan model pembelajaran haruslah sesuai dengan tujuan pembelajaran yang dirumuskan. Model pembelajaran yang digunakan guru seharusnya dapat membantu proses analisis siswa. Salah satu model tersebut adalah model pembelajaran Problem Based Learning. Pengajaran berbasis masalah digunakan untuk merangsang berpikir tingkat tinggi dalam situasi berorientasi masalah, termasuk belajar bagaimana belajar. Pengajaran berbasis masalah tidak dapat dilaksanakan jika guru tidak mengembangkan lingkungan kelas yang memungkinkan terjadinya pertukaran ide secara terbuka. Intinya, siswa dihadapkan pada situasi masalah yang otentik dan bermakna yang dapat menantang siswa untuk memecahkannya (Nurhadi, 2004). Model ini cocok diterapkan pada mata pelajaran akuntansi karena mata pelajaran ini menuntut siswa untuk dapat memiliki keterampilan dalam melakukan pencatatan seperti pencatatan ke dalam jurnal, membuat kertas kerja dan sebagainya. Yang mana keterampilan tersebut dapat dilatih setahap demi setahap.

Menurut Anies (2003), "Model problem-based learning adalah suatu metode instruksional yang mempunyai ciri-ciri penggunaan masalah nyata sebagai konteks siswa yang mempelajari cara berpikir kritis serta keterampilan dalam memecahkan masalah”. Problem Based Learning (PBL) merupakan pembelajaran yang melibatkan peserta didik secara langsung dalam suatu mata pelajaran yang memerlukan praktek. Menurut Boud and Felleti (1997), "Problem Based Learning is an approach to structuring the curriculum involves confronting students with problems from practice with provide a stimulus from learning". (Problem Based Learning adalah sebuah pendekatan untuk menyusun kurikulum yang melibatkan peserta didik dalam menghadapi masalah-masalah dari praktek yang memberikan stimulus untuk pembelajaran).

Berdasarkan uraian di atas dapat disimpulkan bahwa model Problem Based Learning merupakan model pembelajaran yang melibatkan siswa dengan masalah nyata yang sesuai minat dan perhatiannya, sehingga motivasi dan rasa ingin tahu menjadi meningkat. Dengan demikian, siswa diharapkan dapat mengembangkan cara berfikir dan keterampilan yang lebih tinggi. Seperti metode pembelajaran lainnya, PBL memiliki kekuatan 
dan kelemahan. PBL merupakan salah satu model pembelajaran yang memberdayakan daya fikir, kreativitas, dan partisipasi siswa dalam pembelajaran. Hal ini sejalan dengan konsep belajar bahwa belajar adalah perubahan tingkah laku. Perubahan tingkah laku siswa akan dililhat baik jika prestasi belajarnya juga baik. Pengertian prestasi menurut Kamus Besar Bahasa Indonesia (1997), adalah hasil yang telah dicapai (dari yang telah dilakukan, dikerjakan, dan sebagainya). Sedangkan Prestasi belajar berarti penguasaan pengetahuan atau keterampilan yang dikembangkan oleh mata pelajaran, lazimnya ditunjukkan dengan nilai tes atau angka nilai yang diberikan oleh guru. Berdasarkan kedua pengertian ini dapat disimpulkan bahwa "Prestasi belajar adalah kemampuan yang menunjukkan kecakapan siswa dalam menguasai pelajaran yang telah disampaikan oleh guru". Menurut pendapat Oemar (2008), "Hasil belajar menunjuk pada prestasi belajar". Menurut beliau, prestasi merupakan suatu hal yang penting untuk diketahui karena dengan adanya prestasi yang diwujudkan dalam bentuk angka, simbol, maupun kalimat dapat diketahui tingkat keberhasilan siswa dalam mengikuti kegiatan belajar. Prestasi belajar berfungsi sebagai indikator keberhasilan siswa dalam suatu mata pelajaran, juga berfungsi sebagai indikator kualitas suatu lembaga pendidikan. Prestasi belajar dapat memberikan suatu kepuasan tersendiri baik bagi para siswa maupun sekolah yang menyelenggarakan pendidikan. Dari latar belakang masalah yang telah dibahas sebelumnya, peneliti merasa perlu mengadakan suatu penelitian yang bertujuan memperbaiki prestasi belajar akuntansi siswa. Hal itu yang menjadikan peneliti tertarik mengadakan penelitian dengan mengambil judul Penerapan Model Pembelajaran Problem Based Learning Untuk Meningkatkan Prestasi Belajar Akuntansi Pada Siswa Kelas XI MA Al Hidayah Muara Telang Kabupaten Banyu Asin.

\section{METODE}

Penelitian ini bertujuan untuk meningkatkan prestasi belajar akuntansi. Oleh karena itu, peneliti menggunakan pendekatan Penelitian Tindakan Kelas (PTK) karena melalui PTK inilah diharapkan selain diterapkan kepada anak didik juga dapat memperbaiki mekanisme pembelajaran sebelumnya. Menurut Kunandar dalam Iskandar (2009), "PTK adalah merupakan suatu kegiatan yang dilakukan oleh guru atau bersama-sama dengan orang lain (kolaborasi) yang bertujuan untuk memperbaiki atau meningkatkan mutu proses pembelajaran di kelasnya”. Siklus PTK dilakukan melalui empat tahap, yaitu: perencanaan tindakan, pelaksanaan tindakan, pengamatan atau observasi, dan refleksi. Secara keseluruhan keempat tahapan dalam PTK ini membentuk suatu siklus. Siklus ini kemudian diikuti oleh siklus-siklus lain secara bersinambungan seperti sebuah spiral. Untuk mempermudah siklus yang dimaksud dalam penelitian ini, akan digambarkan siklus PTK sebagai berikut:

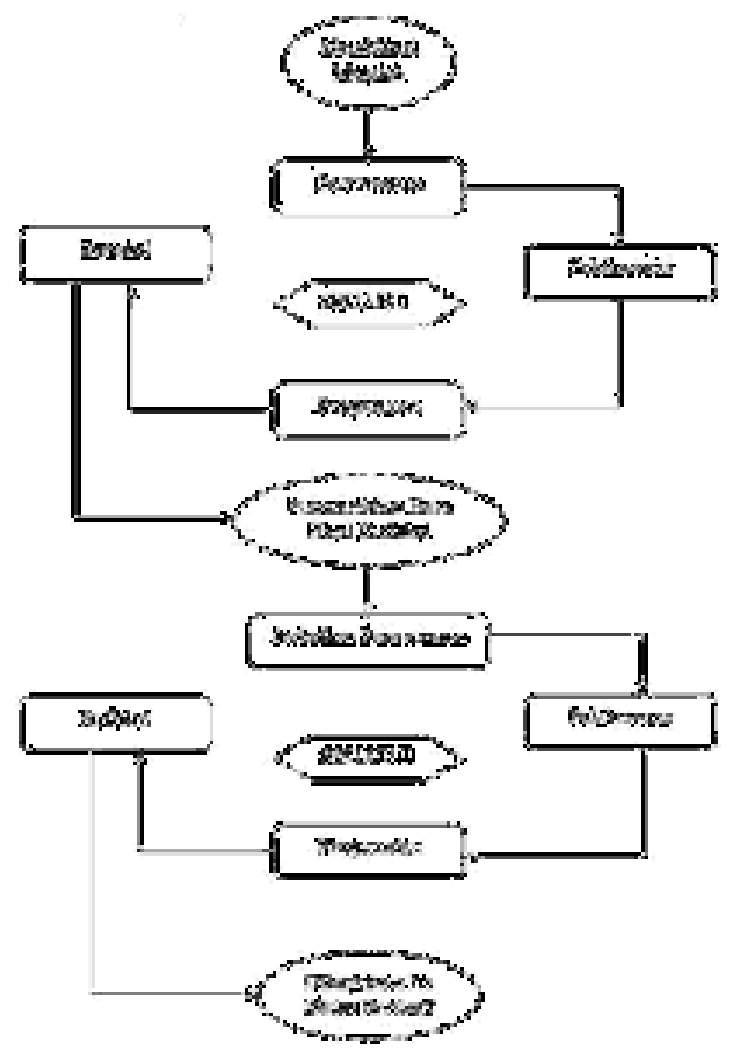




\section{Gambar 1. Siklus Penelitian PTK}

Dalam Penelitian Tindakan Kelas (PTK) ini yang menjadi subjek penelitian adalah siswa kelas XI IPS yang terdiri dari 37 siswa. Teknik pengumpulan data yang digunakan dalam penelitian ini adalah observasi, dokumentasi, dan tes. Sebelum tes dilakukan, tes tersebut harus terlebih dahulu memenuhi persyaratan dengan menggunakan bantuan program SPSS 18.00 for windows. Adapun persyaratan tersebut adalah uji validitas dan reliabilitas. Data penelitian ini dianalisis dengan menggunakan teknik analisis data sebagai berikut: 1) analisis deskriptif komparatif dilakukan dengan membandingkan antara kondisi awal sebelum dilakukannya tindakan dengan hasil yang diperoleh pada siklus I dan siklus II sehingga dapat dilihat adanya perbedaan sebelum dan sesudah dilakukannya tindakan; 2) analisis data kuantitatif digunakan untuk mengolah hasil belajar siswa yang diperoleh dari tes formatif. Data kuantitatif yang digunakan adalah kuantitatif sederhana yang berupa penghitungan nilai rata-rata, nilai tertinggi, nilai terendah, dan persentase jumlah siswa yang mencapai batas ketuntasan. Dari informasi ini dapat diketahui sampai sejauh manakah keberhasilan siswa dalam proses belajar mengajar; dan 3) analisis kualitatif berupa catatan lapangan yang disajikan secara rinci dan lengkap selama proses penelitian berlangsung. Analisis data kualitatif diperoleh berdasarkan hasil observasi, refleksi dari tiap-tiap siklus, dan membandingkan kinerja siswa maupun guru dalam hasil pengamatan dengan parameter atau teori tertentu.

\section{HASIL}

Proses penelitian ini dilakukan dalam dua siklus yang masing-masing siklus terdiri dari 4 tahapan, yaitu: (1) perencanaan tindakan, (2) pelaksanaan tindakan, (3) observasi dan interpretasi, dan (4) analisis dan refleksi tindakan.

\section{Siklus I}

Penerapan pembelajaran ekonomi pada siklus I melalui model Problem Based Learning sebagai berikut:

\section{Perencanaan Tindakan Siklus I}

Tahap perencanaan tindakan I meliputi kegiatan sebagai berikut: 1) guru membuat skenario pembelajaran ekonomi menggunakan metode Problem Based Learning, dengan skenario pembelajaran; menyusun Rencana Pelaksanaan Pembelajaran (RPP) untuk materi membuat laporan keuangan pada perusahaan jasa dengan metode Problem Based Learning; menyusun instrumen penelitian, yang berupa test dan non-test.

\section{Pelaksanaan Tindakan Siklus I}

Pelaksanaan tindakan I dilaksanakan dalam 3 kali pertemuan, seperti yang telah direncanakan, yaitu tanggal 20, 27, dan 28 April 2015 di ruang kelas XI IPS MA Al Hidayah Muara Telang. Pertemuan dilaksanakan selama 4 x 45 menit sesuai dengan skenario pembelajaran dan RPP. Materi pada pelaksanaan tindakan I ini adalah perdagangan internasional. Pada pertemuan ini, guru mendemonstrasikan materi secara jelas dan membentuk kelompok belajar, siswa diminta untuk kerja kelompok mengerjakan soal latihan yang telah dirancang secara khusus dengan metode Problem Based Learning. Kemudian presentasi hasil kerja kelompok setelah soal latihan selesai dikerjakan dengan waktu yang telah ditentukan. Ditutup dengan evaluasi belajar siswa dari siklus I.

\section{Observasi dan Interpretasi}

Peneliti melakukan pengamatan proses pembelajaran ekonomi dengan menggunakan metode Problem Based Learning di kelas XI. Peneliti mengambil posisi di dalam kelas, yaitu di belakang para siswa sambil sesekali berkeliling untuk mengamati dengan jelas jalannya pembelajaran sehingga dapat menilai dengan baik. Pada hari selasa 20 April 2015, guru menyampaikan materi laporan laba-rugi dan laporan perubahan modal pada perusahaan jasa dengan metode Problem Based Learning secara jelas. Kemudian siswa diminta untuk bergabung dengan kelompoknya dan mengerjakan soal secara berkelompok yang hasilnya nanti harus dipresentasikan oleh dua kelompok. Ditutup dengan evaluasi akhir dari siklus I agar hasil belajar dari siklus I dapat segera diketahui. Dari kegiatan tersebut, deskripsi tentang jalannya proses pembelajaran ekonomi dengan metode Problem Based Learning sudah dijelaskan secara rinci dalam pelaksanaan tindakan I.

\section{Refleksi Tindakan Siklus I}

Tindakan refleksi yang dapat diambil berdasarkan pengamatan dan analisis yang telah dilakukan adalah: 1) guru masih harus meluangkan waktu untuk melakukan pendekatan dan monitoring yang merata kepada semua siswa, sehingga setiap siswa yang mengalami kesulitan akan mudah teratasi; 2) guru lebih kreatif dalam menciptakan suasana pembelajaran yang kondusif sehingga siswa memiliki motivasi belajar yang tinggi; dan 3) guru harus memberikan penghargaan kepada siswa yang bisa bekerjasama dan menyelesaikan tugas dengan baik. 
Penghargaan ini bertujuan untuk memacu semangat atau motivasi setiap siswa untuk menyelesaikan pekerjaannya dengan baik dan rapi.

\section{Sikulus II}

\section{Perencanaan Tindakan Siklus II}

Peneliti mengungkapkan bahwa berdasarkan hasil analisis dan refleksi dari siklus I masih terdapat beberapa kekurangan, kemudian disepakati pelaksanaan tindakan pada siklus II akan dilaksanakan selama 3 kali pertemuan, yakni pada hari Selasa 4 Mei, Rabu 5 Mei, dan Selasa 11 Mei 2015 dengan rancangan sebagai berikut: 1) peneliti bersama guru mendiskusikan skenario pembelajaran ekonomi menggunakan metode Problem Based Learning, dengan scenario pembelajaran; 2) peneliti menyusun Rencana Pelaksanaan Pembelajaran (RPP) untuk materi menyusun laporan keuangan neraca pada perusahaan jasa dengan metode Problem Based Learning; dan 3) Peneliti menyusun instrumen penelitian, yang berupa test dan non-test. Instrumen test dinilai dari hasil pekerjaan siswa (evaluasi akhir siklus), sedangkan instrumen non-test dinilai berdasarkan pedoman observasi yang dilakukan oleh peneliti dengan mengamati keaktifan dan sikap siswa selama proses belajar mengajar berlangsung

\section{Pelaksanaan Tindakan Siklus II}

Kegiatan pelaksanaan tindakan siklus II dilaksanakan selama 3 kali pertemuan seperti yang telah direncanakan, yakni pada hari Selasa 4 Mei, Rabu 5 Mei, dan Selasa 11 Mei 2015. Pertemuan dilaksanakan selama 4 x 45 menit sesuai dengan skenario pembelajaran dan RPP. Pelaksanaan tindakan siklus II hampir sama dengan pelaksanaan tindakan siklus I, hanya pada pelaksanaan tindakan II ini terdapat perbaikan yang masih diperlukan dari tindakan I. Materi yang disampaikan pada pelaksanaan tindakan II masih sama dengan pelaksanaan tindakan I, yaitu menyusun laporan keuangan pada perusahaan jasa namun pada siklus II dikhususkan pada penyusunan laporan keuangan neraca. Pada pertemuan siklus II guru menjelaskan dan mendemonstrasikan cara melakukan perdagangan internasional dengan jelas dan dibuka kesempatan tanya jawab, kemudian siswa mengerjakan soal secara berkelompok masih dengan metode yang diterapkan di Siklus I. Dilaksanakan kegiatan diskusi dan presentasi, kegiatan ini ditambah dengan tanya jawab yang lebih efektif untuk membangun pemahaman siswa, ditutup dengan evaluasi akhir Siklus II.

\section{Observasi dan Interpretasi}

Peneliti mengamati proses pembelajaran ekonomi dengan menggunakan metode Problem Based Learning di kelas XI IPS. Peneliti mengambil posisi di dalam kelas, yaitu di belakang para siswa sambil sesekali berkeliling untuk mengamati dengan jelas jalannya pembelajaran sehingga dapat menilai dengan baik. Pada hari Selasa 4 Mei 2015, guru menyampaikan materi laporan keuangan neraca pada perusahaan jasa dengan metode Problem Based Learning secara jelas. Kemudian siswa diminta untuk bergabung dengan kelompoknya dan mengerjakan soal secara berkelompok yang hasilnya nanti harus dipresentasikan oleh dua kelompok. Ditutup dengan evaluasi akhir dari siklus II agar hasil belajar dari siklus II dapat segera diketahui. Dari kegiatan tersebut, deskripsi tentang jalannya proses pembelajaran ekonomi dengan metode Problem Based Learning sudah dijelaskan secara rinci dalam pelaksanaan tindakan II.

\section{Refleksi Tindakan Siklus II}

Tindakan refleksi yang dapat diambil berdasarkan pengamatan dan analisis yang telah dilakukan adalah :1) guru lebih kreatif dalam menciptakan suasana pembelajaran yang kondusif sehingga siswa memiliki minat dan motivasi belajar yang tinggi; 2) guru lebih inovatif dalam menggunakan berbagai model dan metode pembelajaran pada saat mengajar sehingga siswa lebih bersemangat dalam mengikuti pelajaran dan tidak cepat bosan. Setiap siklus yang diterapkan pada proses pembelajaran dengan model Problem Based Learning mampu meningkatkan prestasi belajar siswa. Hal tersebut dapat dilihat dari tabel berikut ini:

Tabel 1. Penerapan Model Problem Based Learning

\begin{tabular}{lccc}
\hline \multicolumn{1}{c}{ Aspek yang diteliti } & \multicolumn{2}{c}{ Persentase Capaian } & \multirow{2}{*}{ Peningkatan } \\
\cline { 2 - 3 } \multicolumn{1}{c}{ Model Problem Based Learning) } & Siklus I & Siklus II & \\
\hline Pemberian masalah & $90 \%$ & $90 \%$ & - \\
Pembagian kelompok & $75 \%$ & $85 \%$ & $10 \%$ \\
Pengarahan diskusi kelompok & $80 \%$ & $90 \%$ & $10 \%$ \\
Penyelesaian masalah & $80 \%$ & $90 \%$ & $10 \%$ \\
Refleksi atau evaluasi & $64 \%$ & $88 \%$ & $24 \%$ \\
Rata-rata & $\mathbf{7 7 , 8 \%}$ & $\mathbf{8 8 , 6 \%}$ & $10,8 \%$ \\
\hline
\end{tabular}

(Sumber: Data primer yang diolah, 2015) 
Tabel 2. Ketuntasan Prestasi Belajar Siswa

\begin{tabular}{lllllcc}
\hline & \multicolumn{3}{c}{ Jumlah Siswa } & \multicolumn{3}{c}{ Persentase } \\
\cline { 2 - 7 } Kriteria & $\begin{array}{c}\text { Sebelum } \\
\text { Penerapan }\end{array}$ & $\begin{array}{c}\text { Siklus } \\
\text { I }\end{array}$ & $\begin{array}{c}\text { Siklus } \\
\text { II }\end{array}$ & $\begin{array}{c}\text { Sebelum } \\
\text { Penerapan }\end{array}$ & $\begin{array}{c}\text { Siklus } \\
\text { I }\end{array}$ & $\begin{array}{c}\text { Siklus } \\
\text { II }\end{array}$ \\
\hline Tuntas & 25 & 28 & 35 & 67,57 & 75,68 & 94,59 \\
Tidak & 12 & 9 & 2 & 32,43 & 24,32 & 5,41 \\
Tuntas & & & & & & \\
\hline
\end{tabular}

(Sumber: Data primer yang diolah, 2015)

Berdasarkan tabel data yang disajikan pada siklus I dan siklus II di atas diperoleh prestasi belajar yang mengalami peningkatan. Model Problem Based Learning berdampak positif terhadap kegiatan pembelajaran ekonomi. Deskripsi hasil penelitian dari siklus I sampai siklus II dapat dijelaskan sebagai berikut:

Sebelum melaksanakan siklus I, peneliti melakukan survei awal untuk mengetahui kondisi yang ada di MA Al Hidayah Muara Telang. Dari hasil survei ini, peneliti menemukan bahwa prestasi belajar ekonomi pada siswa kelas XI IPS masih kurang optimal, yaitu siswa masih kurang antusias mengikuti pembelajaran dan hasil evaluasi belajarnya kurang maksimal. Oleh karena itu, peneliti mengadakan diskusi dengan guru kelas dan mencari solusi untuk mengatasi permasalahan tersebut, yaitu dengan menerapkan model Problem Based Learning (PBL). Pembelajaran kelompok dan kegiatan tanya jawab dalam presentasi diharapkan dapat membangun interaksi edukatif antara siswa dengan guru serta meningkatkan pemahaman melalui diskusi dalam memecahkan masalah.

Peneliti dibantu guru kelas kemudian menyusun Rencana Pelaksanaan Pembelajaran (RPP) guna melaksanakan kegiatan siklus I. Materi pada pelaksanaan tindakan siklus I ini adalah perdagangan internasional. Guru memberikan materi dengan mendemonstrasikan (modelling) penyusunan laporan keuangan laba rugi dan perubahan modal. Kemudian siswa diminta mengerjakan soal dengan kelompok belajar mengenai materi yang telah diajarkan. Setiap kelompok terdiri dari 6 siswa agar siswa dapat belajar bekerjasama dengan siswa yang lain. Setelah selesai, siswa diminta untuk dapat mempresentasikan hasil pekerjaannya, sehingga pengetahuan yang diperoleh siswa tidak hanya dari guru, melainkan juga dari menyaksikan secara langsung proses yang dicontohkan oleh teman sekelas.

Dari hasil pengamatan terhadap proses belajar mengajar ekonomi pada siklus I masih terdapat kekurangan dan kelemahan, yaitu siswa masih kurang aktif dalam mengikuti pembelajaran. Hal ini dapat dilihat dari respon siswa pada saat apersepsi dan dominasi beberapa siswa dalam mengemukakan pendapatnya dan dalam mengajukan pertanyaan selama proses pembelajaran berlangsung serta dapat dilihat juga dalam kegiatan kerja kelompok, ada beberapa siswa yang belum berpartisipasi. Selain itu, kesempatan presentasi untuk tanya jawab juga masih diabaikan para siswa yang tidak maju. Karena itu, peneliti mencari solusi dan menyusun rencana pembelajaran siklus II untuk mengatasi kekurangan dan kelemahan dalam pembelajaran ekonomi pada siklus I. Materi pembelajaran pada siklus II masih sama hanya saja dikhususkan pada penyusunan neraca. Dalam pelaksanaan siklus II ini siswa terlihat lebih antusias dengan metode Problem Based Learning yang telah diterapkan sebelumnya, selain siswa menjadi aktif, siswa juga merasa tidak segan bertanya dan berdiskusi dengan teman satu kelompoknya untuk mencari masalah dan menemukan jawabannya.

Berdasarkan hasil pengamatan terhadap proses belajar mengajar ekonomi pada siklus II, prestasi belajar siswa menunjukkan peningkatan. Pencapaian prestasi belajar siswa mengalami peningkatan, ini ditunjukkan dari banyaknya siswa yang sudah mencapai batas ketuntasan minimal yaitu sebesar 75,68\% atau sebanyak 25 siswa pada siklus I dan 94,59\% atau sebanyak 35 siswa pada siklus II. Siswa yang sebelumnya kurang aktif saat pembelajaran, sekarang menjadi lebih antusias dan lebih merespon apersepsi yang diberikan oleh guru. Siswa yang sebelumnya tidak bisa bekerjasama dalam kelompok, pada siklus II ini sudah dapat bekerjasama dengan siswa lain dalam kelompok dengan baik. Kegiatan presentasi dengan tanya jawab oleh guru juga lebih efektif. Meskipun begitu, masih diperlukan juga motivasi dan pendekatan dari guru untuk mendukung berhasilnya proses belajar mengajar ekonomi. Masalah yang dihadapi pada pembelajaran ekonomi sudah dapat teratasi dengan cara penerapan model Problem Based Learning yang secara langsung dapat meningkatkan prestasi belajar siswa.

\section{PEMBAHASAN}

Penerapan model Problem Based Learning (PBL) merupakan penelitian tindakan kelas yang bertujuan untuk meningkatkan prestasi belajar ekonomi siswa. Penelitian dilakukan dengan menerapkan dua siklus pembelajaran dengan metode yang sama pada tiap siklusnya, yaitu metode Problem Based Learning (PBL). Penelitian Tindakan 
Kelas (Classroom Action Research) ini dilaksanakan dalam dua siklus. Setiap siklus dilaksanakan dalam empat tahap, yaitu: (1) perencanaan tindakan, (2) pelaksanaan tindakan, (3) observasi dan interpretasi, dan (4) analisis dan refleksi tindakan. Dalam proses pembelajaran di sekolah, pada hakekatnya yang berperan aktif adalah siswa, sedangkan guru berperan sebagai fasilitator. Dengan demikian, metode mengajar seharusnya beralih dari lecturbased format menjadi studentactive approach atau student-centered instruction. Salah satu bentuk pembelajaran yang menerapkan student-active approach atau student-centered instruction adalah model Problem Based Learning. Dengan adanya penerapan Problem Based Learning yang merupakan model pembelajaran inovatif, peran guru sebagai pendidik harus bisa membangkitkan minat belajar siswa, motivasi belajar dan partisipasi siswa dalam proses pembelajaran sehingga prestasi belajar siswa akan mengalami peningkatan dibandingkan dengan sebelumnya yang masih menerapkan metode konvensional ceramah.

Nurhadi dalam Trianto (2009:96) mengemukakan bahwa "Model pembelajaran Problem Based Learning merupakan model pembelajaran yang melibatkan siswa dengan masalah nyata yang sesuai minat dan perhatiannya yang memberdayakan daya fikir, kreativitas, dan partisipasi siswa dalam pembelajaran sehingga motivasi dan rasa ingin tahu menjadi meningkat". Oleh karena itu, siswa diharapkan dapat mengembangkan cara berfikir dan keterampilan yang lebih tinggi. Penerapan model Problem Based Learning menghadapkan siswa pada suatu permasalahan sehingga mereka termotivasi untuk mencari jawaban dengan cara berulang-ulang memecahkan masalah yang dihadapinya yang pada akhirnya dapat menyelesaikan masalah tersebut sehingga dapat meningkatkan rasa percaya diri siswa akan kemampuannya.

Peningkatan rasa percaya diri siswa akan kemampuannya dapat membuat siswa menjadi lebih aktif dan berpartisipatif dalam proses pembelajaran karena siswa merasa tertantang untuk menyelesaikan setiap tugas yang diberikan oleh guru dan membuat siswa menjadi lebih yakin dapat meraih prestasi belajar ekonomi yang lebih tinggi daripada pencapaian sebelumnya. Hal ini terbukti pada pencapaian prestasi belajar siswa yang mengalami peningkatan sebesar 18,91\% (prestasi belajar siswa pada siklus I sebesar 75,68\% atau sebanyak 25 siswa yang tuntas sedangkan pada siklus II mengalami peningkatan menjadi 94,59\% atau sebanyak 35 siswa yang dinyatakan tuntas).

Berdasarkan tindakan tersebut, guru dan peneliti berhasil melaksanakan pembelajaran ekonomi yang menyenangkan sehingga prestasi belajar ekonomi dapat meningkat. Selain itu, dapat meningkatkan kinerja guru dalam melaksanakan pembelajaran yang efektif dan menarik. Keberhasilan pembelajaran ekonomi dengan menggunakan model Problem Based Learning dapat dilihat dari indikator-indikator sebagai berikut: 1) Kegiatan belajar mengajar di kelas yang berpusat pada siswa (student center) sehingga siswa aktif dalam proses pembelajaran baik dalam diskusi atau kerja kelompok, presentasi, tanya jawab. Kegiatan ini dapat melatih siswa dalam bekerja sama dan menumbuhkan semangat kebersamaan di dalam kelompok belajar; 2) Suasana pembelajaran santai, menyenangkan, dan sesuai dengan keinginan siswa sehingga membuat siswa lebih berminat dan nyaman dalam belajar. Hal ini terlihat dari semangat dan antusiasme siswa dalam mengikuti pelajaran terus mengalami peningkatan; 3) Siswa mampu memahami materi yang telah diberikan dan lebih percaya diri dengan kemampuannya. Hal ini terjadi karena siswa yang mulanya belum memahami benar materi yang disampaikan oleh guru dapat menanyakannya lebih lanjut dan leluasa baik secara langsung kepada guru maupun peneliti atau teman satu kelompoknya.

Penerapan metode Problem Based Learning dalam proses belajar mengajar dapat meningkatkan pencapaian hasil belajar dan prestasi belajar siswa. Hasil belajar tersebut dinyatakan tuntas karena secara umum pencapaian hasil belajar siswa berada di atas standar batas tuntas yaitu 65 dan mengalami peningkatan dari siklus I sampai siklus II. Hal ini menunjukkan bahwa secara umum siswa telah memahami materi yang disajikan dengan baik pada proses belajar mengajar yang menggunakan model Problem Based Learning (PBL).

\section{SIMPULAN DAN SARAN}

\section{Simpulan}

Model Problem Based Learning (PBL) pada penelitian ini telah dilakukan dalam dua siklus. Tiap siklus dilaksanakan dalam 3 kali pertemuan, dimana pertemuan berlangsung selama $4 \times 45$ menit. Secara keseluruhan penerapan model Problem Based Learning telah dapat meningkatkan prestasi belajar siswa. Hal ini terbukti dari pencapaian nilai rata-rata siswa dan jumlah siswa yang mencapai batas ketuntasan. Pada siklus I nilai rata-rata kelas sebesar 71,14 terjadi peningkatan nilai rata-rata kelas sebesar 3,33 dari sebelum diadakannya tindakan yaitu 67,81. Pada siklus II terjadi peningkatan nilai rata-rata kelas sebesar 10,64 (pada siklus I sebesar 71,14 menjadi 81,78 pada siklus II). Jumlah siswa yang mencapai batas tuntas pada siklus I sebanyak 25 siswa atau 75,68\% sedangkan pada siklus II jumlah siswa yang mencapai batas tuntas sebanyak 35 siswa dari 37 siswa atau sebesar 
94,59\% (mengalami peningkatan sebesar 18,91\%). Penerapan model Problem Based Learning secara rinci dapat meningkatkan minat belajar, motivasi belajar dan partisipasi belajar siswa dalam pembelajaran. Siswa diajak untuk turut serta dalam semua proses pembelajaran. Dengan variasi pembelajaran yang terdiri dari diskusi kelompok, pemecahan masalah, dan presentasi membuat siswa merasakan suasana belajar yang lebih menyenangkan dan materi yang disajikan dalam bentuk masalah yang harus dipecahkan menjadi lebih mudah dipahami siswa sehingga dapat meningkatkan prestasi belajar siswa.

\section{Saran}

Berkaitan dengan kesimpulan di atas, maka peneliti dapat mengajukan saran-saran sebagai berikut: 1) Bagi siswa: a) Siswa meningkatkan kerja sama dalam arti yang positif, baik dengan guru maupun dengan siswa yang lain dalam proses belajar mengajar; b) Siswa meningkatkan ketrampilan berkomunikasi yang baik dimana hal ini pada akhirnya akan sangat bermanfaat bagi siswa terutama dalam meningkatkan rasa percaya diri akan kemampuan yang dimiliki dalam menjalani kehidupan di masa yang akan datang; dan c) Siswa harus berperan aktif dalam proses pembelajaran serta harus membuka diri dan tidak menganggap pusat informasi adalah guru, namun bisa berasal dari teman, buku, televisi maupun internet. Bagi Guru: a) Guru meningkatkan kemampuannya dalam mengembangkan dan menyampaikan materi serta dalam mengelola kelas dengan menerapkan pembelajaran inovatif, sehingga proses dan hasil pembelajaran dapat terus meningkat seiring dengan peningkatan kemampuan yang dimilikinya; b) Guru mengembangkan model dan metode pembelajaran yang mendorong siswa untuk aktif berpartisipasi dan lebih mudah dalam memahami materi pembelajaran; c) Guru yang belum menerapkan model Problem Based Learning dapat menerapkan model tersebut dalam pembelajaran akuntansi dengan variasi pembelajaran yang menarik sehingga dapat meningkatkan minat, perhatian dan motivasi siswa untuk memahami materi yang disajikan yang pada akhirnya dapat meningkatkan prestasi belajar siswa; d) Guru lebih optimal dalam memanfaatkan sarana dan prasarana yang sudah disediakan oleh pihak sekolah sebagai alat bantu dalam pengembangan media pembelajaran; e) Kerjasama guru dan siswa selama proses pembelajaran harus diperhatikan sehingga suasana pembelajaran menjadi lebih kondusif dan siswa dapat lebih mudah memahami materi pembelajaran. Bagi Sekolah: a) Kepala Sekolah lebih memberikan kesempatan kepada guru-guru mata pelajaran untuk mengikuti workshop yang berhubungan dengan model dan metode pembelajaran inovatif; b) Sekolah mengadakan pertemuan MGMP pada tingkat sekolah yang diadakan rutin untuk mendiskusikan permasalahan pendidikan dan pembelajaran. Bagi Orang Tua: Orang tua memfasilitasi kegiatan belajar anak, sehingga dengan fasilitas belajar yang memadai anak akan lebih merasa nyaman dan bersemangat dalam belajar. Dengan demikian, pada akhirnya dapat meningkatkan prestasi belajar anak.

\section{DAFTAR RUJUKAN}

Anies. (2003). Problem Based Learning. Artikel. Tersedia pada http://www.suaramerdeka.com/harian/0304/28/kha2.ht Diunduh tanggal 11 Januari 2015.

Boud, David \& Feletti, Grahame I. (1997). The Challenge of Problem Based Learning. London: Kogan Page Limited. Oemar Hamalik. 2008. Belajar dan Teori Belajar. Jakarta: Bumi Aksara.

Iskandar. (2009). Penelitian Tindakan Kelas. Jakarta: Gaung Persada (GP) Press.

Yona Abidin. (2011). Desain Sistem Pembelajaran dalam Konteks Kurikulum 2013. Bandung: Refika Aditama. Nurhadi dkk. (2004). Pembelajaran Kontekstual dan Penerapannya dalam KBK. Malang: Universitas Negeri Malang.

Anonim. (1997). Kamus Besar Bahasa Indonesia. Balai Pustaka. Departemen Pendidikan Kebudayaan. 